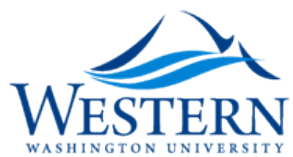

Western Washington University

Western CEDAR

Spring 2007

\title{
Beyond the Wall: Reinterpreting Jefferson's Danbury Address
}

Johann N. Neem

Western Washington University, johann.neem@wwu.edu

Follow this and additional works at: https:// cedar.wwu.edu/history_facpubs

Part of the History Commons

\section{Recommended Citation}

Neem, Johann N., "Beyond the Wall: Reinterpreting Jefferson's Danbury Address" (2007). History Faculty and Staff Publications. 7. https://cedar.wwu.edu/history_facpubs/7

This Article is brought to you for free and open access by the History at Western CEDAR. It has been accepted for inclusion in History Faculty and Staff Publications by an authorized administrator of Western CEDAR. For more information, please contact westerncedar@wwu.edu. 


\section{Notes AND Documents}

\section{Beyond the Wall \\ Reinterpreting Jefferson's Danbury Address}

JOHANN N. NEEM

In 1802, President Thomas Jefferson replied to an address from a committee of the Danbury Baptist Association. He thanked them for their "esteem and approbation" and used the opportunity to respond to longstanding Federalist and ministerial attacks on Jefferson's supposed atheism. Rather than express his own religious views, historians generally argue, Jefferson's response instead focused on the importance of protecting religious freedom. From a political angle, this position strengthened the ties between New England's dissenters and Jefferson's Republican party. From an intellectual perspective, it represented Jefferson's own deep commitment to the separation of church and state. As he wrote in his letter to the Baptists of Danbury, Connecticut, the first amendment of the federal constitution erected a "wall of separation between church and State."

Johann N. Neem is assistant professor of history at Western Washington University. He is completing his manuscript, "Creating a Nation of Joiners: Democracy and Civil Society in Early National Massachusetts." The author thanks Ari Helo, James H. Hutson, Robert M. S. McDonald, Peter S. Onuf, Leonard J. Sadosky, Gordon S. Wood, and the FER's reviewers for their comments.

1. Thomas Jefferson, "To Messrs. Nehemiah Dodge and Others, a Committee of the Danbury Baptist Association, in the State of Connecticut," Jan. 1, 1802. The most accurate transcription can be found in Daniel L. Dreisbach, Thomas Fefferson and the Wall of Separation between Church and State (New York, 2002), 48. The letter is also reprinted in Thomas fefferson: Writings, ed. Merrill D. Peterson (New York, 1984), 510, but it contains a typographical error. In the second paragraph of the address, Jefferson writes that "the legitimate powers of 
In the twentieth century, ever since Justice Hugo Black invoked it in a majority opinion in the 1947 case of Everson v. Board of Education, which upheld the legitimacy of using public funds for school buses for children attending Catholic schools, Jefferson's Danbury address has become a touchstone for how the first amendment should be interpreted. ${ }^{2}$ How to understand the wall metaphor has thus become a major historical, political, and legal enterprise. It should not be surprising, then, that tempers flared when James H. Hutson, the chief of the Manuscript Division at the Library of Congress, chose to lower the Supreme Court's wall in his reinterpretation of the Danbury address as part of a Library of Congress 1998 exhibit. The ensuing debate focused on the meaning of Jefferson's wall. Hutson argues that historians and jurists are wrong to read the wall metaphor literally. Instead, he suggests, the primary purpose of Jefferson's letter was political, a conclusion he drew after an FBI lab uncovered phrases Jefferson had deleted from his original draft. The letter, Hutson writes, was an opportunity for Jefferson to publicly rebut his critics and to shore up the allegiance of dissenting religious groups in New England. If the letter was unreliable because of its political context, Hutson continues, perhaps we ought to look at Jefferson's practices as a statesman to understand how committed he was to the wall. Hutson then points out that Jefferson continuously breached the wall as an elected officeholder. He attended religious services in the U.S. House of Representatives while president and, following retirement, felt no compunction about attending services in the Albemarle County Courthouse. While president, he allowed various congregations to use federal office

government reach actions only." In the Peterson collection, and other collections, the word legislative is submitted instead of legitimate. See Dreisbach, Thomas Fefferson and the Wall of Separation, 48, fn71, for discussion. All other Jefferson citations in this essay are from the Peterson collection above unless otherwise stated.

2. Everson v. Board of Education, 330 U.S. 1 (1947). See Dreisbach, Thomas Fefferson and the Wall of Separation, 95-106; Daniel L. Dreisbach, " 'Sowing Useful Truths and Principles': The Danbury Baptists, Thomas Jefferson, and the "Wall of Separation," Fournal of Church and State 39 (Summer 1997), 455-501, esp. 491-95. For intriguing discussions of the historical processes behind the separation of church and state, see Mark D. McGarvie, One Nation Under Law: America's Early National Struggles to Separate Church and State (DeKalb, IL, 2004); Philip Hamburger, Separation of Church and State (Cambridge, MA, 2002). 
buildings to hold their own services. Clearly, Hutson concludes, Jefferson's wall was lower and more permeable than the wall that the Supreme Court has constructed over the course of the twentieth century. ${ }^{3}$

Hutson's paper was seized upon by the Christian Coalition to argue that it is "a liberal myth" that Jefferson intended for his words "to be used as a justification for expelling religious expression from the public square." ${ }^{.4}$ In turn, twenty-four scholars signed a paper written by Robert M. O'Neil and Robert S. Alley accusing Hutson's work of being “unbalanced" and "flawed." As Hutson notes, Jefferson's wall metaphor has become "a shorthand expression for two radically different, passionately held visions of church-state relations in the United States."

Hutson's argument was addressed by leading scholars in a 1999 William and Mary Quarterly forum. Some supported Hutson's claim that the Supreme Court had erected a higher, less permeable wall than Jefferson's. Thomas E. Buckley, for example, noted that Jefferson consistently made references to God in his public addresses. If Jefferson had intended to banish prayer or Christianity from the public sphere, Buckley wrote, he would not have used religious language himself. Others argued that our contemporary understanding of the wall is correct, and that Jefferson believed in a strong and constantly fortified barrier preventing any contact between church and state. ${ }^{7}$

3. James H. Hutson, "Thomas Jefferson's Letter to the Danbury Baptists: A Controversy Rejoined," William and Mary Quarterly 56 (Oct. 1999), 775-90.

4. Quoted in American Atheists, Inc., "Christian Coalition Plays Fast and Loose with Facts as Vote on Religious Freedom Amendment Looms," Web posting, June 4, 1998. Available at http://www.atheists.org/flash.line/rfa12.htm.

5. 'Leading Church-State Scholars Refute Library of Congress' Views on Thomas Jefferson and Church-State Separation," July 29, 1998, press release, Americans United for Separation of Church and State.

6. Hutson, "Thomas Jefferson's Letter," 776.

7. Hutson's essay and the responses appeared in the William and Mary Quarterly 56 (Oct. 1999), 775-824. See Hutson, "Thomas Jefferson's Letter"; Robert M. O'Neil, "The 'Wall of Separation' and Thomas Jefferson's Views on Religious Liberty," 791-94; Thomas E. Buckley, S. J., "Reflections on a Wall," 795-800; Edwin S. Gaustad, "Thomas Jefferson, Danbury Baptists, and 'Eternal Hostility'," 801-804; Daniel L. Dreisbach, "Thomas Jefferson and the Danbury Baptists Revisited," 805-16; Isaac Kramnick and R. Laurence Moore, "The Baptists, the Bureau, and the Case of the Missing Lines," 817-22; James H. Hutson, "James H. Hutson Responds," 823-24. For the debate over the separation of church and state, see also Thomas E. Buckley, S. J, "The Religious Rhetoric of Thomas 
The job of historians has its normative dimensions. But historians are also bound to make their judgments in a way true to the past, and thus the historians" debate must be about what Jefferson meant. The "wall of separation" is, I argue, not the real point of Jefferson's Danbury address. The focus on Jefferson's use of the wall metaphor overlooks the most important part of the Danbury address, both in its historical context and for us today. The "wall of separation" was not Jefferson's end, it was his means. The real point of the letter, which perhaps even most Baptists did not realize, lies in the next sentence, which concerns what would happen on the other side of the wall, in civil society: "I shall see with sincere satisfaction the progress of those sentiments which tend to restore to man his natural rights, convinced he has no natural right in opposition to his social duties."

Jefferson believed that by erecting a wall between church and state, he could protect free inquiry and, by doing so, aid the process by which a purified Christianity housed in reason rather than faith would became America's civil religion. The wall of separation was not intended to banish religion from the public sphere of civil society. Instead, it was intended to prohibit an alliance between ministers and politicians that would limit free inquiry. Free inquiry would allow persons to question centuries of fabricated mysticism invented by ministers. In time American Christianity would be transformed from a faith-based religion to one premised on reason and more compatible with Jefferson's conception of human nature. Jefferson did not say this more explicitly only because his political goal, as Hutson demonstrates, was to cement his alliance with New England dissenters. Still, he could not resist hinting at his ultimate end. ${ }^{9}$ Jefferson told the Baptists that the wall of separation may protect

Jefferson," in The Founders on God and Government, ed. Daniel L. Dreisbach, Mark D. Hall, and Jeffrey H. Morrison (Lanham, MD, 2004), 53-82; Dreisbach, Thomas Fefferson and the Wall of Separation, 25-70; Hamburger, Separation of Church and State, 144-89; James H. Hutson, ed., Religion and the New Republic: Faith in the Founding of America (Lanham, MD, 2000); Isaac Kramnick and R. Laurence Moore, The Godless Constitution: The Case Against Religious Correctness (New York, 1996), esp. 88-109.

8. Jefferson, "Danbury Address."

9. I agree with Thomas E. Buckley, S. J., who links Jeffersonian rhetoric to the development of American civil religion. But the civil religion Jefferson imagined was far different than that envisioned by many evangelicals during Jefferson's era and our own. See Buckley, "Religious Rhetoric of Thomas Jefferson." 
them from New England's Standing Order in the short run, but in the long run their ideas, like those of the Standing Order, were slated for extinction.

Like other Enlightenment thinkers, Jefferson believed that reason must strip away the layers of mythology piled up by generations of ignorance. ${ }^{10}$ Once this happened, the natural goodness of man would finally flourish. This was history's logic. The only thing preventing it from happening was what Jefferson's friend John Adams once referred to as the conspiracy of kings and popes. ${ }^{11}$ The first step in the historical process towards enlightenment was purification. Christianity had been corrupted, Jefferson believed, since Jesus's crucifixion. Popes, priests, and ministers had constructed an elaborate artifice that masked Jesus's true teachings. ${ }^{12}$ The free use of reason, vigilantly protected by the first amendment, would allow enlightened persons slowly to dismantle these myths. The result would be a Christianity with tenets compatible with reason. As Jefferson colorfully wrote in 1813, "Abstracting what is really

10. According to Henry May, The Enlightenment in America (New York, 1976), 153, the members of the Revolutionary Enlightenment "were sure that they lived in a new age. For them, Enlightenment was an unsparing sunrise, revealing the wickedness and folly of ancient ideas and institutions, illuminating also the fundamental goodness of man." Similarly, Ernst Cassirer notes in The Philosophy of the Enlightenment (Princeton, NJ, 1951), 220, the Enlightenment's notion of progress was about removing the cultural debris that interposed itself between Reason and the social world: "History shows how reason gradually overcomes these obstacles, how it realizes its true destiny." For a discussion of Jefferson's historical optimism, see Joyce O. Appleby, "What Is Still American in the Political Philosophy of Thomas Jefferson?" William and Mary Quarterly 39 (Apr. 1982), 287-309.

11. John Adams, "A Dissertation on the Canon and Feudal Law" (1765), in The Works of Fohn Adams, ed. Charles Francis Adams (Boston, MA, 1851), 3: 447-64. Also reprinted in C. Bradley Thompson, ed., The Revolutionary Writings of John Adams (Indianapolis, IN, 2000), 21.

12. Edwin S. Gaustad, Sworn on the Altar of God: A Religious Biography of Thomas Fefferson (Grand Rapids, MI, 1996), 111-46. See also Jean M. Yarbrough, American Virtues: Thomas Fefferson on the Character of a Free People (Lawrence, KS, 1998), 182-93; Kramnick and Moore, Godless Constitution, 88109; Charles B. Sanford, The Religious Life of Thomas Fefferson (Charlottesville, VA, 1984); Eugene R. Sheridan's Introduction to Fefferson's Extract from the Gospels: "The Philosophy of Jesus" and "The Life and Morals of Fesus," ed. Dickinson W. Adams \& Ruth W. Lester (Princeton, NJ, 1983), 3-42. 
his [Jesus's] from the rubbish in which it is buried, easily distinguished by its luster from the dross of his biographers, and as separable from that as the diamond from the dunghill, we have the outlines of a system of the most sublime morality which has ever fallen from the lips of man."13

One way to understand how Jefferson conceptualized the religious public sphere is to compare it to how he thought about the public sphere more generally. Historians influenced by Jürgen Habermas's conception of "the public sphere of civil society" have recently argued that to Jefferson and his Republican allies, public opinion was trustworthy only when it was the direct expression of the people in civil society. But, if the state meddled with the freedoms of the public sphere, public opinion could be corrupted. ${ }^{14}$ To Republicans, the Federalists' effort to crack down on opposition during the 1790s threatened to pervert public opinion. The passage of the Sedition Act marked the culmination of Federalist efforts to manage the public sphere. While Federalists may have seen the Sedition Act as a way to check the forces of chaos, to Republicans it was an affront to the foundation of liberty, namely the ability of the people to watch over their leaders. ${ }^{15}$ Republicans condemned the Federalists' ac-

13. Jefferson to William Short, Oct. 31, 1819, 1430-33, at 1431.

14. Johann N. Neem, "Freedom of Association in the Early Republic: The Republican Party, the Whiskey Rebellion, and the Philadelphia and New York Cordwainers' Cases," Pennsylvania Magazine of History and Biography 127 (July 2003), 259-90; Albrecht Koschnik, "The Democratic Societies of Philadelphia and the Limits of the American Public Sphere, circa 1793-1795," William and Mary Quarterly 68 (July 2001), 615-36; John L. Brooke, "Ancient Lodges and Self-Created Societies: Voluntary Association and the Public Sphere in the Early Republic," Launching the Extended Republic: The Federalist Era ed. Ronald Hoffman and Peter J. Albert, (Charlottesville, VA, 1996), 273-377; Stanley Elkins and Eric McKitrick, The Age of Federalism (New York, 1993), 451-61. On the idea of the public sphere, see Jürgen Habermas, The Structural Transformation of the Public Sphere: An Inquiry into a Category of Bourgeois Society, trans. Thomas Burger (Cambridge, MA, 1989).

15. On the Federalists" intentions see Joanne B. Freeman, "Explaining the Unexplainable: The Cultural Context of the Sedition Act," in The Democratic Experiment: New Directions in American Political History, ed. Meg Jacobs, William J. Novak, and Julian E. Zelizer (Princeton, NJ, 2003), 20-49; Seth Cotlar, "The Federalists' Transatlantic Cultural Offensive of 1798 and the Moderation of American Democratic Discourse," in Beyond the Founders: New Approaches to the Politi- 
tion as violations of the freedoms of speech and of association. They suggested that a politically powerful Federalist minority sought to use its power to silence the "natural" Republican majority. Jefferson, of course, was at the forefront of the battle against the Sedition Act, composing the Kentucky Resolutions to limit its reach. ${ }^{16}$ Jefferson believed that the virtuous American citizenry understood that the Federalists were secret monarchists bent on undermining America's republican experiment. He worried, however, that Federalists' use of state power to silence dissenters would corrupt the citizenry's natural republican virtue and allow Federalists to remain in control. The only way to ensure that the people's virtue could be preserved was to protect the public sphere. If a wall separated the state from the public sphere, Jefferson was confident that the virtuous American majority would triumph over a powerful but dangerous minority. ${ }^{17}$ Freedom of speech could slice through Federalist lies.

Jefferson saw religion through a similar lens as politics. Progress in religion, as in politics, required a "wall of separation" between the religious public sphere and the state in order to prevent a powerful minority, such as the Congregationalist Standing Order in New England, from corrupting a naturally virtuous Christian majority. If the wall stood high, Jefferson believed, then Federalists and their ministerial allies would not be able to use state power to propagate their mystical Christianity and a more rational and pure public Christianity would prevail. Central to this vision was the role of free inquiry in the public sphere. In Notes on the State of Virginia, Jefferson wrote that "reason and free enquiry are the only effectual agents against error. Give a loose to them, they will support true religion, by bringing every false one to their tribunal, to the test of their investigation. They are the natural enemies of error." He maintained that "reason and experiment [in the sciences] have been indulged, and error has fled before them. It is error alone which needs the support of government. Truth can stand by itself."18 In his draft of Virginia's Statute for Religious Freedom, Jefferson was confident "that truth is

cal History of the Early American Republic, ed. Jeffrey L. Pasley, Andrew W. Robertson, and David Waldstreicher (Chapel Hill, NC, 2004), 274-99.

16. Jefferson, "Draft of the Kentucky Resolutions," Oct. 1798, 449-56.

17. Peter S. Onuf, Jefferson's Empire: The Language of American Nationhood (Charlottesville, VA, 2000), 80-108.

18. Jefferson, Notes on the State of Virginia (1787), 284-85. 
great and will prevail if left to herself." ${ }^{19}$ In an 1801 letter, Jefferson argued that New Englanders would come over to the Republican side only once they overthrew "the dominion of the clergy." Reason, once guaranteed its freedom in the public sphere by the first amendment, would divest Christianity "of the rags in which they [ministers of the established churches] have enveloped it." The result would be the restoration of Christianity to its "original purity and simplicity." 20

The first step in purifying America's public Christianity, then, was to guarantee the freedom of inquiry by preventing an alliance between ministers and the state. The wall would do this. The second step was for reason to do its work and remove the "rags" in which ministers had wrapped Jesus's teachings. This purification process was very much on Jefferson's mind when he composed the Danbury address. The harsh attacks he had endured during the election of 1800 inspired Jefferson to think more deeply about his own religious beliefs and the role of religion in public life. ${ }^{21}$ In 1800, he wrote Dr. Benjamin Rush that his own views on Christianity "ought to displease neither the rational Christian nor Deists," although he admitted that evangelical Christians would remain hostile. But, as he reiterated later in the wall metaphor, he swore "on the altar of god, eternal hostility against every form of tyranny over the mind of man. ${ }^{922}$ In a series of letters written to Dr. Joseph Priestley between 1800 and 1804, he expressed his admiration for Priestley's Unitarian writings and hoped that reason would restore Christianity to its roots. ${ }^{23}$ In an 1803 letter to Benjamin Rush, he wrote, "To the corruptions of Christianity I am indeed opposed; but not the genuine precepts of Jesus

19. Jefferson, "A Bill for Establishing Religious Freedom," 346-48.

20. Jefferson to Moses Robinson, Mar. 23, 1801, 1087-88.

21. On the religious rhetoric of the election of 1800, see Robert M. S. McDonald, "Was There a Religious Revolution of 1800?," in The Revolution of 1800: Democracy, Race, \& the New Republic, ed. James S. Horn, Jan Ellen Lewis, and Peter S. Onuf (Charlottesville, VA, 2002), 173-98; Hamburger, Separation of Church and State, 111-20; Frank Lambert, " 'God and a Religious President . . . (or) Jefferson and No God': Campaigning for a Voter-Imposed Religious Test in 1800," Journal of Church and State 39 (Autumn 1997), 769-89; Sheridan, "Introduction," 10-12.

22. Jefferson to Dr. Benjamin Rush, Sept. 23, 1800, 1080-82.

23. Jefferson to Dr. Joseph Priestley, Jan. 27, 1800, 1072-74; Jefferson to Priestley, Mar. 21, 1801, 1085-87; Jefferson to Priestly, Apr. 9, 1803, 1120-22; Jefferson to Priestley, Jan. 29, 1804, 1141-43. 
himself." ${ }^{24}$ These letters emphasize Jefferson's disgust with ministers who "look backwards, not forwards, for improvement." duty, therefore, was to find the means by which America's public religion would be purified.

Jefferson privately undertook his sacred duty while still president. His faith had been shaped by reading English Unitarian Joseph Priestley's An History of the Corruptions of Christianity some time after 1793. He was inspired again in 1803 when Priestley sent Jefferson his Socrates and fesus Compared in which Priestley affirmed that Jesus's teachings were of the highest moral caliber once restored to their original purity. In an 1803 letter to Rush, Jefferson copied Priestley's method and drafted a "syllabus of an estimate of the merit of the doctrines of Jesus, compared with those of others." Jefferson argued that neither ancient philosophers nor Jews had adequately understood "our duties to others." Jesus, on the other hand, expressed the principle of benevolence and thus provided a moral code for how we should relate to each other. Jesus might have elaborated more had he not been sacrificed to "the jealousy \& combination of the altar and the throne." His few words reached us "disfigured by the corruptions" of subsequent interpreters. Jefferson also sent copies of his letter and syllabus to his daughters, and to some friends, including Priestley. Their responses were sufficiently positive that Jefferson undertook the work of recovering Jesus's true teachings. In early 1804 he ordered several copies of the New Testament including two copies of the same edition in English. Over the next two months Jefferson put scissors to paper to excise the rational Jesus from the Bible's depiction of him. The result was a story of Jesus's life and teachings stripped of the supernatural and embodying the rational morality that Jefferson ascribed to him. Jefferson's "Philosophy of Jesus of Nazareth" was never published during his lifetime but it serves as a testament to how seriously and honestly Jefferson undertook his own religious quest. ${ }^{26}$

Jefferson believed Jesus's original teachings were "the most perfect and sublime that has ever been taught by man" because they accorded

24. Jefferson to Rush, Apr. 21, 1803, 1122-26.

25. Jefferson to Priestly, Mar. 21, 1801, 1085-87; Jefferson to Elbridge Gerry, Jan. 26, 1799, 1057.

26. Jefferson to Rush, Apr. 21, 1803, 1122-26; On the intellectual background to Jefferson's decision to draft the Syllabus and the Philosophy of Jesus, see Sheridan, "Introduction." 
with human nature. Jefferson, following Lord Kames and other Scottish Enlightenment thinkers, believed that God had endowed each person with an innate moral sense. The moral sense provided all persons knowledge of right and wrong. The moral sense, like any faculty, could be strengthened by education and exercise or weakened by disuse and corruption. Its existence, however, was universal. ${ }^{27}$ Reason, or science, not only would purify Christianity and restore Jesus's original teachings, but also teach us about our own natures. People were born naturally virtuous, and it was only thanks to the work of scheming priests and politicians that they were corrupted. Following the purification of Christianity by reason, the next step in the historical process would be to allow the moral sense the opportunity to reign.

Any effort by the state to impose religious belief would destroy the conditions that make true religion possible. In the first half of the sentence in the Danbury address in which Jefferson invoked the wall of separation, he wrote, "religion is a matter which lies solely between man and his God" and the "legitimate actions of government reach actions only, and not opinions." ${ }^{\prime 28}$ This was both a statement on the limits of state power and an expression of theological principle. To Jefferson, faith came naturally through the use of reason and the moral sense. Any state action to impose religious belief would corrupt citizens' virtue by forcing them to be hypocrites, externally committing themselves to the state's mandates while struggling to maintain internally the commitments of conscience. $^{29}$

Because Jefferson believed in an innate moral sense, he feared the corrupting influence of the clergy but not atheism. As he wrote in Notes

27. Jefferson to Rush, Apr. 21, 1803, 1125. On the influence of moral sense theory on Jefferson, see Yarbrough, American Virtues; Yehoshua Arieli, Individualism and Nationalism in American Ideology (Cambridge, MA, 1964), chs. 6-8; Adrienne Koch, The Philosophy of Thomas fefferson (Gloucester, MA, 1957), 1522. Jefferson's most clear expressions of his moral sense theory are in two letters: Jefferson to Martha Jefferson, Dec. 11, 1783, 784-85; Jefferson to Peter Carr, Aug. 10, 1787, 900-905.

28. Jefferson, "Danbury Address."

29. On the theological ramifications of Jefferson's conception of faith, see Sheridan, "Introduction," 4, 9-10. See also Mark De Wolfe Howe, The Garden and the Wilderness: Religion and Government in American Constitutional History (Chicago, IL, 1965). 
on the State of Virginia, "it does me no injury for my neighbor to say there are twenty gods, or no god. It neither picks my pocket nor breaks my leg. ${ }^{930}$ In the Virginia Statute for Religious Freedom, he maintained that "our civil rights have no dependence on religious opinions." ${ }^{11} \mathrm{He}$ repeated this claim years later in an 1814 letter. Belief in a god cannot be the basis of morality, Jefferson pointed out, since, "if we did a good act merely from the love of God and a belief that it is pleasing to Him, whence arises the morality of the Atheist?" He continued that "it is idle to say, as some do, that no such being [a moral atheist] exists." The only conclusion was that atheists' "virtue, then, must have some other foundation than the love of God," namely the moral sense. ${ }^{32}$

The ultimate trajectory of history, Jefferson believed, was toward replacing a Christianity based on faith and the authority of ministers with one premised on reason and compatible with our natural constitution. He believed that Jesus's teachings embodied the "principles of a pure deism. ${ }^{933}$ In an 1822 letter to Dr. Benjamin Waterhouse, Jefferson boldly proclaimed, misguidedly in the days of the Second Great Awakening, that "there is not a young man now living in the United States who will not die an Unitarian." In this letter, Jefferson's Unitarianism was premised on three principles: the existence of one perfect God, the existence of a future state of rewards and punishments, and the obligation to be good to one's fellow creatures. Everything else must be abandoned, starting with the divinity of Jesus, miracles, and the mystical Trinity. Jefferson makes clear that the means to securing this new public Christianity is the wall of separation. The victory of reason over faith is dependent on maintaining complete freedom of inquiry and of conscience, and the wall protected Christianity from an alliance between ministers and politicians. Jefferson could "rejoice that in this blessed country of free inquiry and belief, which has surrendered its creed to neither kings nor priests, the genuine doctrine of one only God is reviving." Jefferson added that unless free inquiry remained protected, Unitarians, like previous keepers of the faith, might make the same mistake of "fabricating formulas of creed

30. Jefferson, Notes on the State of Virginia, 284-85.

31. Jefferson, "A Bill for Establishing Religious Freedom," 346-48.

32. Jefferson to Thomas Law, June 13, 1814, 1335-39.

33. Jefferson to Priestley, Apr. 9, 1803, 1120-22, at 1121. 
and confessions of faith, the same engines" which had originally corrupted Jesus's teaching. ${ }^{34}$ Only free inquiry could sustain the purity of the Christian religion.

Let us now return to Jefferson's words in the Danbury address: "I shall see with sincere satisfaction the progress of those sentiments which tend to restore to man his natural rights, convinced he has no natural right in opposition to his social duties." ${ }^{\prime 5}$ What Jefferson wishes is, first, "progress," or the purification of Christianity by reason and ensured by the free inquiry that is protected by the "wall of separation." The purification process shall restore man to his "natural rights," meaning those rights delineated in the Declaration of Independence and our own nature, especially the freedom of conscience. Once the progress of reason has purified Christianity and "restored to man his natural rights," the moral sense would ensure that "no natural right" operated "in opposition to his social duties" because our nature, Jefferson agreed with Lord Kames, was made for society. ${ }^{36}$ Jefferson famously wrote that "the Creator would indeed have been a bungling artist, had he intended man for a social animal, without planting in him social dispositions. ${ }^{137}$

This reading of Jefferson's intent in the Danbury address is compatible with other aspects of Jefferson's historical thinking. In politics, Jefferson believed the American Revolution was a purifying moment in which the conspiracy of kings and popes had been overthrown and the "laws of nature and of nature's God" had reasserted themselves. ${ }^{38}$ The

34. Jefferson to Dr. Benjamin Waterhouse, June 26, 1822, 1458-59. On the divinity of Jesus, in addition to his letter to Waterhouse, see Jefferson to Priestley, Apr. 9, 1803, 1120-22; Jefferson to Rush, Apr. 21, 1803, 1122-23; Jefferson to Short, Aug. 4, 1820, 1435-40.

35. Jefferson, "Danbury Address."

36. Lord Kames, like Jefferson, marveled at the Creator's genius in implanting a moral sense as "part of the human system" to make it possible for humans to "to live in society; and because there can be no society among creatures who prey upon one another, it was necessary, in the first place, to provide against mutual injuries. Further; man is the weakest of all creatures separately, and the very strongest in society. Therefore mutual assistance is the principal end of society." See Henry Home, Lord Kames, Essays on the Principles of Morality and Natural Religion. In two parts. (Edinburgh, Scotland, 1751), 67.

37. Jefferson to Thomas Law, June 13, 1814, 1335-39, at 1337. See also Jefferson to Carr, Aug. 10, 1787, 900-905, at 901-2.

38. "A Declaration by the Representatives of the United States of America, in General Congress Assembled" July 4, 1776, 19-24, at 19. 


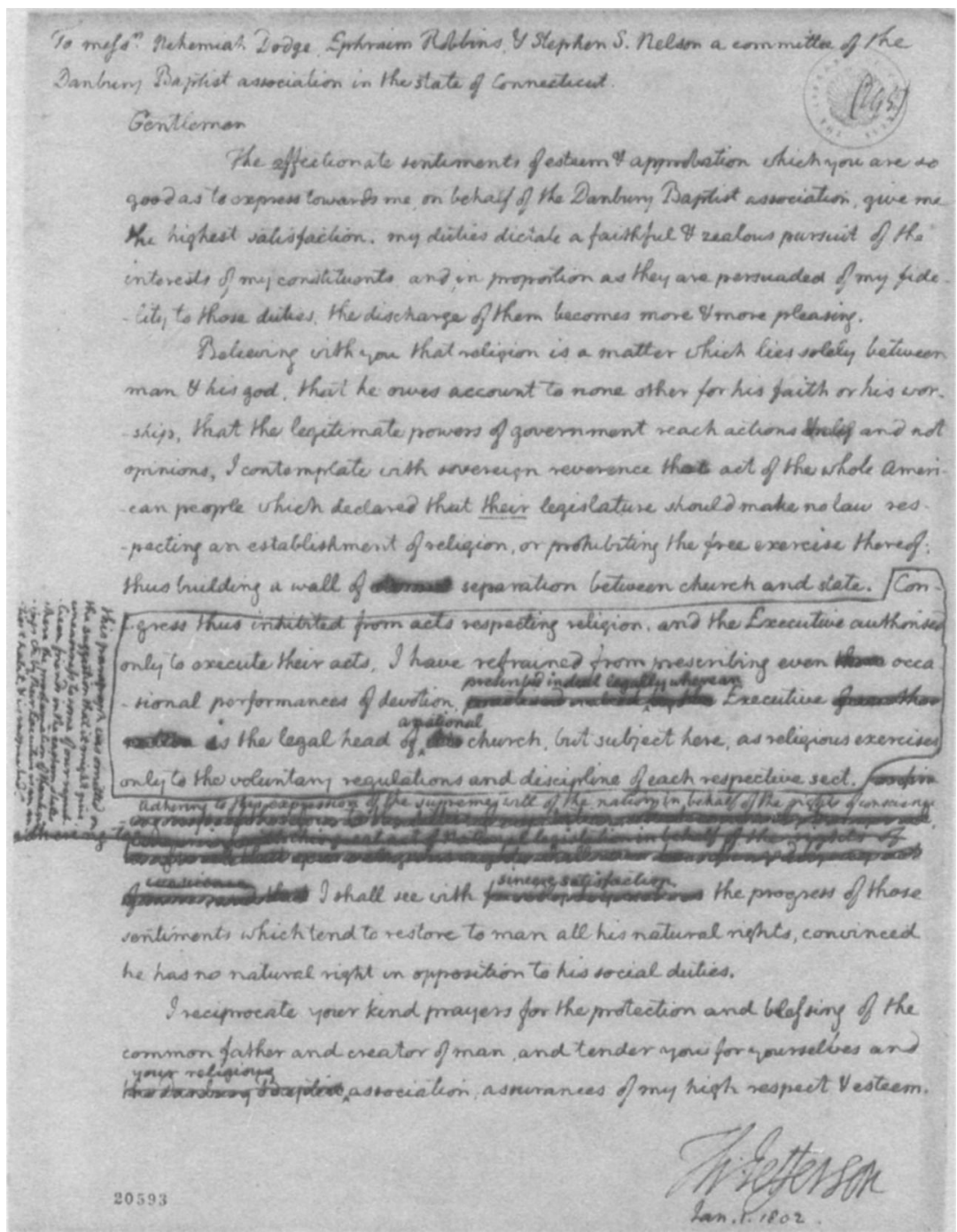

Figure 1: Jefferson's Danbury Address. Courtesy Manuscript Division of the Library of Congress. 
Revolution, Jefferson wrote, "presented us an album on which we were free to write what we pleased." $" 39$ It removed the shackles of the past and allowed Americans to organize political society according to nature rather than custom. As he wrote late in life, in the American Revolution natural man "burst the chains under which monkish ignorance and superstition" had bound him. ${ }^{40}$ Jefferson felt the same about the Revolution of $1800 .{ }^{41}$ In the early heady days of the French Revolution, Jefferson was so confident that purification was the first step towards a more natural political order that he averred that he would rather see "half the earth desolated" if there could be an uncorrupted "Adam \& Eve left in every country, \& left free." ${ }^{\prime 2}$ Similarly, Jefferson counted on the progressive purification of southern slaveholders' moral senses as the first step in liberating the slaves. ${ }^{43}$ Jefferson's yeoman republic was itself intended to protect the natural virtue of every citizen from corruption. On his farm, each yeoman would remain independent and pure. In commerce, as in politics and religion, relations of dependence would corrupt those "breasts" which God "has made his peculiar deposit for substantial and genuine virtue. $"{ }^{\prime 4}$ Jefferson was so convinced that the American Revolution had revived natural man, with his innate moral sense, that he suggested, "State a moral case to a ploughman \& a professor. The former will decide it as well, \& often better than the latter, because he has not been led astray by artificial rules. ${ }^{945}$ Stripped of their power by the forces of reason, neither politicians nor priests, nor professors for that matter, could corrupt the pure moral nature of American citizens.

Jefferson's wall, far from working as a means to purify Christianity by subjecting it to reason, strengthened faith-based Christianity in the public sphere. Jefferson had some sense that his goals were being subverted. Jefferson's wall allowed the clergy to organize citizens in civil society independent of the state, and during the first half of the nineteenth

39. Jefferson to John Cartwright, June 5, 1824, 1490-96.

40. Jefferson to Roger C. Weightman, June 24, 1826, 1516-17.

41. Onuf, Fefferson's Empire, 80-108; Jefferson, "First Inaugural Address," Mar. 4, 1801, 493-96; Jefferson to John Dickinson, Mar. 6, 1801, 1084-85.

42. Jefferson to Short, Jan. 3, 1793, 1003-6.

43. Ari Helo and Peter S. Onuf, "Jefferson, Morality, and the Problem of Slavery," William and Mary Quarterly 60 (July 2003), 583-614.

44. Jefferson, Query 19 in Notes on the State of Virginia, 290-91.

45. Jefferson to Carr, Aug. 10, 1787, 900-905, at 901-2. 
To messrs. Nehemiah Dodge, Ephraim Robbins, \& Stephen S. Nelson, a committee of the Danbury Baptist association in the state of Connecticut.

\section{Gentlemen}

The affectionate sentiments of esteem and approbation which you are so good as to express towards me, on behalf of the Danbury Baptist association, give me the highest satisfaction. my duties dictate a faithful \& zealous pursuit of the interests of my constituents, \& in proportion as they are persuaded of my fidelity to those duties, the discharge of them becomes more and more pleasing.

Believing with you that religion is a matter which lies solely between Man \& his God, that he owes account to none other for his faith or his worship, that the legitimate powers of government reach actions only, \& not opinions, I contemplate with sovereign reverence that act of the whole American people which declared that their legislature should "make no law respecting an establishment of religion, or prohibiting the free exercise thereof," thus building a wall of separation between Church \& State. adhering to this expression of the supreme will of the nation in behalf of the rights of conscience, I shall see with sincere satisfaction the progress of those sentiments which tend to restore to man all his natural rights, convinced he has no natural right in opposition to his social duties. I reciprocate your kind prayers for the protection \& blessing of the common father and creator of man, and tender you for yourselves \& your religious association, assurances of my high respect \& esteem.

Th: Fefferson

Fan. 1. 1802.

Figure 2: Transcription of Jefferson's Danbury Address. Daniel L. Dreisbach, Thomas Fefferson and the Wall of Separation between Church and State (New York: New York University Press, 2002), 48. 
century ministers established thousands of moral reform societies to strengthen Christianity's influence over American public life. ${ }^{46}$ The New England Congregational minister Jedidiah Morse asked Jefferson to serve on the board of one of these associations, and Jefferson balked. He worried that Morse and other ministers were misusing the wall by building up a movement in civil society that would, in time, undermine republican government. To Morse, Jefferson wrote: "I shall not undertake to draw the line of demarcation between private associations of laudable views and unimposing numbers, and those whose magnitude may rivalise and jeopardise the march of regular government. Yet such a line does exist." ${ }^{\prime 47}$ In civil society, Jefferson discovered, private voluntary associations could shape public opinion in ways that threatened his faith in progress.

The wall of separation did not do the job Jefferson assigned it. Nonetheless, the historical meaning of Jefferson's Danbury address cannot be understood without taking account of Jefferson's true end, and the wall as the means toward that end. He hoped that by protecting the separation of church and state and maintaining religious liberty, Americans would in time adopt a civil religion that was more enlightened and less reliant on faith. Today's tensions between church and state are in part a result of Jefferson's mistaken philosophy of history.

46. Mark Y. Hanley, Beyond a Christian Commonwealth: The Protestant Quarrel with the American Republic, 1830-1860 (Chapel Hill, NC, 1994); Paul S. Boyer, Urban Masses and Moral Order in America, 1820-1920 (Cambridge, MA, 1978); Clifford S. Griffin, Their Brothers' Keepers: Moral Stewardship in the United States, 1800-1865 (New Brunswick, NJ, 1960); Charles Foster, An Errand of Mercy: The Evangelical United Front, 1790-1825 (Chapel Hill, NC, 1960).

47. Jefferson to Jedidiah Morse, Mar. 6, 1822, 1454-58. 